\title{
The Four Kingdoms and Other Chronological Conceptions in the Book of Daniel
}

\author{
Michael Segal
}

1

\section{Introduction}

The four kingdoms scheme plays a prominent role in the book of Daniel itself, and lies at the foundation of Nebuchadnezzar's dream in chapter 2 and Daniel's vision in chapter 7 . The motif of four earthly empires followed by a heavenly kingdom, whose roots can be traced to surrounding cultures, serves both chronological and ideological-theological functions within Daniel itself. In the current study, I want to focus on the former, and place it in the larger context of chronological conceptions throughout the book as a whole. At the same time, the discussion of the ideological worldview of the Danielic authors will be discussed as it relates to these chronological conceptions. All of the chronological schemes in Daniel to be discussed here share a number of basic features, although specific aspects and emphases vary from chapter to chapter. It will be suggested that one aspect, common to the chronological worldview of most early Jewish and Christian apocalypses, is in fact not present in all of the Daniel apocalypses, and this serves as a litmus test for the milieu and historical background in which they were composed. ${ }^{1}$ The following five characteristics or features are common to some or all of the Daniel apocalypses.

These characteristics relate to a chronological span of time, and not to an event at a specific moment. Within an apocalypse one finds allusions to individual incidents, but the apocalypse as a whole refers to a longer period that includes the individual event. This is common among contemporaneous apocalyptic compositions, such as Jubilees or the Apocalypse of Weeks. However, those are

1 Daniel 2 is included here alongside the apocalypses in chapters 7-12. Although it appears within the context of the narrative about Nebuchadnezzar's challenge to the Babylonian wise men, the dream in that chapter appears to originate from a similar apocalyptic context as the vision in chapter 7 . Therefore, for the purposes of this discussion, I will refer to the dream about the statue of different metals as an apocalypse, even if it does not fully correspond to all aspects of the description of the genre as proposed by various scholars. 
different in that their span of history begins from the creation of the world. In contrast, throughout Daniel the starting point for this span is a specific historical referent and, in particular, a point in time related to the rise and reign of a foreign empire. Thus, the four kingdoms dream in chapter 2 and vision in chapter 7 begin explicitly with the Babylonian kingdom and reach historically until the Hellenistic empire. The "7o weeks" vision in Daniel 9 covers a period of 490 years, generally assumed to start with the final years of the Babylonian empire. I have argued that it in fact begins with the rise of the Persians, and continues once again through the Hellenistic period. ${ }^{2}$ Daniel 8 covers a similar period, from Media and Persia through Greece. Daniel 11 also begins with Persian kings and then offers a detailed description of the complex interactions between the Seleucids and Ptolemies.

This short survey of the historical periods covered in the Daniel apocalypses leads to the unsurprising conclusion that the primary interest of their authors lay in their contemporary condition. In all of the passages, the current empire (Greece) is the focus of the apocalypse, but is always complemented or contrasted with the immediately prior empire (Persia, and sometimes Media). In the four kingdoms passages, the historical perspective is expanded back even further to include Babylonia. ${ }^{3}$

The expanded perspective to include at least one, but sometimes multiple, additional empires, including their rise and fall, is part of the internal logic and argument put forth - the current oppressive empire might have the upper hand, but they too will fall one day, just as previous empires did before them. ${ }^{4}$

2 Michael Segal, "The Chronological Conception of the Persian Period in Daniel 9," JAJ 2 (2011): 283-303.

3 The four kingdoms pattern was adopted from non-Israelite/Jewish sources, and adapted to match the Judean reality. In the original (Persian) form of this scheme, Assyria appeared in place of Babylon, leading to a more logical progression of the kingdoms, since Media did indeed take over part of the Assyrian empire. While the origins of the four kingdoms scheme are beyond the scope of this study, they have been discussed extensively in scholarship; see e.g., Joseph W. Swain, "The Theory of the Four Monarchies: Opposition History under the Roman Empire," CP 35 (1940): 1-21; David Flusser, "The Four Empires in the Fourth Sybil and in the Book of Daniel," IOS 2 (1972): 148-75; Louis F. Hartman and Alexander A. Di Lella, The Book of Daniel: A New Translation with Introduction and Commentary, AB 23 (Garden City, NY: Doubleday, 1978), 30-33; Doron Mendels, "The Five Empires: A Note on a Propagandistic 'Topos', AJP 102 (1981): 330-37; John J. Collins, A Commentary on the Book of Daniel, Hermeneia (Minneapolis: Fortress, 1993), 166-70.

4 For a general discussion of the subversive nature of early Jewish apocalyptic literature (including Daniel) against the world empires, see the extensive discussions of Anathea Portier-Young, Apocalypse Against Empire: Theologies of Resistance in Early Judaism (Grand Rapids: Eerdmans, 2011). 
The succession of empires is at the same time inherently related to periodization, which has a chronological conception at its core. Many Second Temple apocalyptic texts can be characterized by their use of set divisions of times according to which the events of history occur, along the chronological span described above. Thus, the Apocalypse of Weeks divides all of universal history into ten weeks, and each of these can be further subdivided into "days." ${ }^{5}$ Jubilees dates the events from the creation of the world to the return to the land of Israel according to a system of jubilees and weeks. ${ }^{6}$ The Apocryphon of Jeremiah dates the period between two blasphemous kings, presumably Nebuchadnezzar and Antiochus IV, as ten jubilees. ${ }^{7}$

This final period is equal in length to the "seventy weeks", or 490, years of Daniel 9. In that sense, one finds the notion of periodization in Daniel as well. However, the scheme in that chapter is different than what is found, for example, in the Apocalypse of Weeks, since, in the latter, the periods are of generally equal length and, therefore, divide history according to a predetermined schematic plan (see section on determinism below). In Daniel 9, the periods in question are not of equal lengths, but are rather divided into seven weeks, sixty-two weeks, and one week (9:24-27). This uneven division is the result of an attempt by this author to fit the events of the Persian period (parallel to the

5 See the article in this volume by Loren Stuckenbruck.

6 See James C. VanderKam, From Revelation to Canon: Studies in Hebrew Bible and Second Temple Literature, JSJs 62 (Leiden: Brill, 200o), 522-44; Michael Segal, The Book of Jubilees: Rewritten Bible, Redaction, Ideology and Theology, JsJs 117 (Leiden: Brill, 2007), chapter 4 and passim.

7 See Devorah Dimant, ed., "B. Apocryphon of Jeremiah," in Qumran Cave 4.XXI: Parabiblical Texts, Part 4: Pseudo-Prophetic Texts, DJD 30 (Oxford: Clarendon, 2001), 91-26o, at 190-191 (a composite text based upon multiple Qumran Cave 4 manuscripts). Bennie H. Reynolds III (Between Symbolism and Realism: The Use of Symbolic and Non-Symbolic Language in Ancient Jewish Apocalypses 333-63 B.C.E., JAJSup 8 [Göttingen: Vandenhoeck \& Ruprecht, 2011], 295-97) has argued that the first blaspheming king is a Persian monarch, since according to his reading of the fragment, the king will arise only after the Babylonian exile. $\mathrm{He}$, therefore, suggests either Cyrus or Darius I as potential candidates for this epithet, but neither is particularly appropriate. However, it seems more likely to me that the period of ten jubilees in this passage begins one generation before the destruction of the temple and its accompanying exile, and the arrival of the blaspheming king (= Nebuchadnezzar) is associated with this destruction. See my discussion of this text in "Interpreting History in Qumran Texts," in The Religious Worldviews Reflected in the Dead Sea Scrolls: Proceedings of the Fourteenth International Symposium of the Orion Center for the Study of the Dead Sea Scrolls and Associated Literature, ed. M. Kister, M. Segal, and R. Clements, STDJ 127 (Leiden: Brill, 2018), 212-44, at 232-36. 
seven weeks) and those of his immediate context (the final week) into a larger typological timeframe. In the context of this apocalypse, it is not the periodization itself which is ideologically or theologically significant, but rather the beginning and end of that longer period. ${ }^{8}$

The four kingdoms pattern is also based on a conception of periodization, although they are not of standard, unified length. Instead of a week or jubilee, or some multiple of these periods, the kingdoms are of varying lengths and characters. In this sense the divisions into periods loses some of its deterministic implications, according to which the periods were all part of a carefully devised divine plan. This, however, is achieved through a different approach, since the four kingdoms are predicted in both chapters as part of a divine revelation which is presented as having taken place before most of the chronological span in question, and thus it too is determined, although no more than any other ex eventu prophecy.

\section{Determinism}

Throughout the book, the span of history is presented in the context of prophetic revelations to Daniel (or in the case of chapter 2, to the Babylonian king Nebuchadnezzar). Based upon historical-critical analysis of these passages, and primarily based upon the argument that the time of their composition can be determined by the accuracy of their "predictions," we can determine when each of these passages was composed. When the prophecy is correct across extensive details, then it is likely that it was written ex eventu of the events alluded to throughout. When the prophecy begins to diverge from what we know to actually have taken place, then we can safely conclude that it was composed at the point in the passage at which the divergence begins. The best example of this (in the entire Bible) is the detailed description of interactions between the Ptolemies and Seleucids in Daniel 11, which is accurate through v. 39, and then diverges at v. 40, demonstrating that it was authored right after the events presented up to that point. ${ }^{9}$ The correspondence to the events, which are

8 Segal, "The Chronological Conception.".

9 Anthony A. Bevan, A Short Commentary on the Book of Daniel: For the Use of Students (Cambridge: University Press, 1892), 198-200; James A. Montgomery, A Critical and Exegetical Commentary on the Book of Daniel, ICC (Edinburgh: T\&T Clark, 1927), 464-70; Robert H. Charles, A Critical and Exegetical Commentary on the Book of Daniel (Oxford: Clarendon, 1929), 317-22; Hartman and Di Lella, Daniel, 276, 303-305; Collins, Daniel, 403; Choon-Leong Seow, Daniel (Louisville: Westminster John Knox, 2003), 184-86; Carol A. Newsom with Brennan W. Breed, Daniel: A Commentary, OTL (Louisville: Westminster John Knox, 2014), 358-59. 
presented as if they are predictions, has the result of significantly raising the predictive value of the revelation in the eyes of the reader. If the events that appear in the first part of the apocalypse, which reflect the author's past, came to fruition, then there is a high probability that the truly future predictions will occur as well. When combined at times with the notion of periodization described above, they reflect a developed conception of the nature of the divine control of chronological history.

\section{$5 \quad$ Geopolitical Transformation}

An important, fundamental difference between the four kingdoms motif and standard periodization schemes is frequently overlooked..$^{10}$ According to Daniel 2, the striking of a stone on the foot of the statue led to its destruction in one fell swoop, and to its replacement by a mountain that fills the whole earth. This mountain represents a theocracy in which the God of Heaven rules over the entire world, replacing the earthly empires:

All at once, the iron, clay, bronze, silver, and gold were crushed, and became like chaff of the threshing floors of summer; a wind carried them off until no trace of them was left. But the stone that struck the statue became a great mountain and filled the whole earth.

DAN 2:35 NJPS

In contrast to earthly empires that rise and fall, according to Daniel 2, the Heavenly Kingdom will lead to a complete change in world order. Note that, in fact, according to this vision, the entire statue continues to stand until the appearance of the stone, and then comes crashing down in its entirety, indicating that the empires will continue to coexist until the rise of the heavenly kingdom. In this scheme, the periods do not mark the ends of each empire, since they continue even after the next one rises.

Like the destruction of the statue in chapter 2, which leads to the downfall of all of the earthly empires in one fell swoop, so too chapter 7 envisions a single universal heavenly judgment against all of the same political entities, with a similar result:

10 I have discussed this aspect of both Daniel 2 and 7 in Michael Segal, Dreams, Riddles, and Visions: Textual, Contextual, and Intertextual Approaches to the Book of Daniel, BZAW 455 (Berlin: Walter de Gruyter, 2016), 144-50. 
I looked on. Then, because of the arrogant words that the horn spoke, the beast was killed as I looked on; its body was destroyed and it was consigned to the flames. The dominion of the other beasts was taken away, but an extension of life was given to them for a time and season.

DAN 7:11-12 NJPS

The judgment of the empires is meted out to all of them together, and at a specific time. Their dominion was taken away at this time of collective judgment, and the fourth beast is consigned to fire before the other beasts are put to death. Ultimately, therefore, the emphasis in both the dream and the vision is first and foremost not on the appearance and disappearance of the empires in succession, but on the radical geopolitical transformation that will occur at the time of the heavenly judgment. While this does not negate the notion of periodization, the continued persistence of each of the kingdoms until that endpoint suggests that the most important division is not between the periods of each kingdom, but the overall difference between earthly, historical time and the eschatological period that follows.

The picture is different elsewhere in the Daniel apocalypses, and in particular in chapter 8 . The depiction there is indeed of the rise and fall of successive empires, one at the hand of the next. The two-horned ram representing Media and Persia was unassailable by other beasts (8:4- "and there was none to deliver from his power"), but is ultimately toppled by the he-goat, representing Greece:

I saw him reach the ram and rage at him; he struck the ram and broke its two horns, and the ram was powerless to withstand him. He threw him to the ground and trampled him, and there was none to deliver the ram from his power.

DAN 8:7 NJPS

That vision does in fact describe the deposing of one empire by another, and I suggest that this later apocalypse has generally influenced the interpretation of chapters 2 and 7 to mean the same. ${ }^{11}$ However, the vision in chapter 8 is fundamentally different in three ways from those earlier passages:

11 Scholars generally agree that chapter 7 is the earliest of the apocalypses and that chapter 2 is even earlier. In Michael Segal, "Calculating the End: Inner-Danielic Chronological Developments," VT 68 (2018): 272-96, I suggested that Daniel 8 is the latest of the apocalypses, based upon internal chronological-exegetical considerations. While I am no longer convinced that Daniel 8 is necessarily the latest of the apocalypses, I do think it can be safely concluded that it is later than chapter 7 (and 10:1-12:4); see below. 
(i) It does not reflect the four kingdoms motif. Media and Persia are presented as one kingdom in this vision, but even if they were to be counted separately, there would be only three, and not four, kingdoms. While they overlap in the identification of some of the empires, this is due to the significance of these specific kingdoms to the geopolitical reality, and not because of the dependence upon a specific literary genre or scheme.

(ii) Unlike the four kingdoms motif, in which the kingdoms persist, here there is no doubt that the previous kingdom is removed from the world stage. As noted above, the second kingdom destroyed and deposed the first (that is, it "threw him to the ground and trampled him, and there was none to deliver the ram from his power").

(iii) Chapter 8 offers a fundamentally different perspective regarding the eschaton than chapter 2 and 7 . While the latter place the global transformation and salvation from persecution at a far-off, indeterminate time (see below regarding the interpretation of 7:25), the former specifies a predetermined, relatively short, period of time until the salvation. This difference will be discussed in the following section.

\section{$6 \quad$ Eschatology}

In a number of apocalypses, history culminates in an eschatological moment or era, which is temporally beyond the historical span discussed above. However, the eschaton was not perceived of as a far-off event, but rather the authors of these apocalypses viewed themselves as standing at the cusp of their imminent arrival. This eschatological worldview is fundamental to the conception of Daniel 2, according to which the striking of a stone on the foot of the statue will lead to the transformation into a mountain that fills the whole earth. This mountain represents a theocracy in which the God of Heaven rules over the entire world, replacing the earthly empires:

And in the time of those kings, the God of Heaven will establish a kingdom that shall never be destroyed, a kingdom that shall not be transferred to another people. It will crush and wipe out all these kingdoms, but shall itself last forever.

DAN 2:44 NJPS

This major transformation of the world order is characteristic of the eschatological era as conceived in contemporaneous compositions. Note that there are no dates or precise chronological data regarding the eschaton in this dream and interpretation. 
I have recently suggested a similar understanding of Daniel 7 , based on a new interpretation of a key expression in $7: 25 .{ }^{12}$ This chapter is probably the most intricate in the entire book, including its mythic background and complex theological picture, as well as basic questions of interpretation. I have argued that this chapter should first be interpreted independent of the subsequent apocalypses, in chapters $8-12 .{ }^{13}$ This methodological approach is a result of the general consensus that Daniel 7 is the earliest of the apocalypses (preceded only by the composition of the dream in Daniel 2, dated according to its historical allusions; see especially the Old Greek version of 2:41-42), ${ }^{14}$ as can be demonstrated based upon both its historical allusions and its linguistic differentiation from the later chapters. In my opinion, these later chapters, which according to all scholars were composed subsequent to chapter 7 , read and interpret this earlier chapter and, therefore, will at times change its original meaning and message. ${ }^{15}$ Analysis of the second half of Daniel frequently proceeds from the assumption that each of the four apocalypses (chs. $7 ; 8 ; 9$; 10-12) reflects the same viewpoint, emanating from a single author, or else from a likeminded and interrelated "school" of authors. This assumption is then applied in a harmonistic fashion in the exegesis of the book, both by traditional interpreters and critical scholars, who interpret one apocalypse with the aid of the other. ${ }^{16}$ However, if the apocalyptic visions were not all composed by one author and at one time, then a later apocalypse might be based upon an earlier one.

12 See below, and more extensively Segal, "Calculating the End."

13 For the importance of this methodological assumption regarding the chronological background of Daniel 7, see Segal, "Calculating the End." For its importance for the theological background of Daniel 7, see Segal, Dreams, Riddles, and Visions, ${ }^{150}{ }^{-52}$.

14 See Hartman and Di Lella, Daniel, 141, 148-49.

15 Other scholars have previously proposed complex processes of literary and scribal development for chapters 7-12; cf. e.g., H. L. Ginsberg, Studies in Daniel, TS 14 (New York: Jewish Theological Seminary of America, 1948), 29-40. Closer to the general approach posited here is the statement by R. G. Kratz ("The Visions of Daniel," in The Book of Daniel: Composition and Reception, ed. John. J. Collins and Peter W. Flint, VTSup 83 [Brill: Leiden, 2001], 1:91-113, esp. 94): "the visions accumulate successively. The whole work is a textbook example of inner-Biblical exegesis ...”

16 See the programmatic statement supporting this approach, in the context of Danielic chronology and eschatology, by John J. Collins, "The Meaning of 'the End' in the Book of Daniel," in Of Scribes and Scrolls: Studies on the Hebrew Bible, Intertestamental Judaism, and Christian Origins: Presented to John Strugnell on the Occasion of His Sixtieth Birthday, ed. H. W. Attridge, John J. Collins, and Thomas H. Tobin, S. J., CTSRR 5 (Lanham: University Press of America, 1990), 91-98, esp. 97: "As the book stands, in any case, the visions in chaps. 7-12 must be read as complementary, and not as independent compositions." 
This inner-Danielic interpretation has led to an almost absurd situation, in which the latest layers of the book are those that have determined how exegetes and scholars have interpreted the earlier stages of the book. This is perhaps an unavoidable result for any composition that has developed incrementally through a redactional process. But it is our responsibility to attempt to untangle these complex processes, and avoid the pitfalls of harmonistic, synchronic interpretation that does not distinguish between early and late, and between a source and its interpretation. I offer this pointed critique at many existing studies and commentaries to Daniel, because such an approach silences the voices of these earliest authors, and prevents us from appreciating their writings in a nuanced fashion.

I suggest that this methodological approach is crucial for understanding the chronological conception of Daniel 7, which shares a number of basic characteristics with Daniel 2 already mentioned above: the four kingdoms scheme and the radical geopolitical transformation of the world, culminating in the transfer of dominion from the empires to the (עם) קדישי עליונין (7:18, 22, 27). As I have argued, contrary to the standard translation as "(the people of) the holy ones of the Most High," this title should perhaps be translated as "(the people of) the Most High Holy one(s)," referring to God and His nation Israel. Therefore, chapter 7 presents a similar picture of cosmological transformation as in chapter $2 .{ }^{17}$ But beyond that, I suggest that chapter 7 shares the same eschatological conception as chapter 2 (and other apocalyptic texts).

Verse 25 is fundamental for recognizing this eschatological worldview in Daniel 7. Near the end of the apocalypse in Daniel 7 , it is said that the final horn will speak words against the Most High and think of changing times and law:

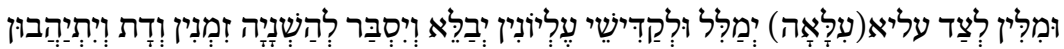

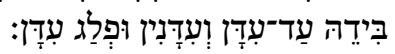

קדישי (aill speak words against the Most High, and will speak (against) עליונין (the Most High Holy One[s]), and will think to change times and

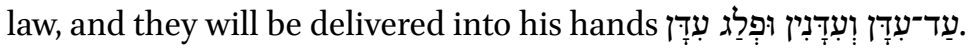

DAN 7:25 MT

The final clause is often translated as "until a time, and times, and half a time" (7:25). The term עִדָּן is generally interpreted here as one year; the use of עדן to

17 See Segal, Dreams, Riddles, and Visions, 132-54, and the larger argument presented there for understanding the theological picture of Daniel 7, according to which the Ancient of Days is YHWH himself. 
mean "year" is attested in Daniel 4, according to which Nebuchadnezzar lived like a beast in the field for שבעה עדנין (4:13, 20, 22, 29), which seemingly refers to a period of seven years. ${ }^{18}$ If עד עד reflects a basic unit of one year, then the plural עדנין can be understood as two years. This can be accomplished either through revocalizing the Aramaic form as a dual plural form here with dual meaning. ${ }^{20}$ Finally, פלג עדג is taken to be another half-year, taking the Aramaic פלג, to mean "half," which is its predominant meaning. ${ }^{21}$ This leads to the sum total of 3.5 years.

A synchronic reading of the book of Daniel seems to support this interpretation, because the length of time of the religious persecution is 3.5 years in other verses in the apocalyptic section of the book. Thus, for example, Dan 9:27

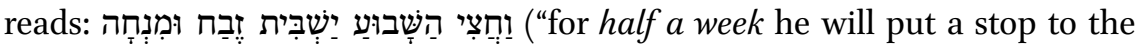
sacrifice and the meal offering"), corresponding to the period described in 7:25 during which the holy ones of the Most High were given into the hands of the little horn. In the context of the "seventy weeks" vision in Daniel 9, in which a week refers to seven years, then the "half a week" during which the sacrifices were stopped can be calculated as 3.5 years.

Returning to the methodological observation above, while this is the meaning of the expression when read in the context of chapters 8-12, I suggest that

18 The term עדן could alternatively be translated as "season" and the expression in Daniel 4 as "seven seasons," but the extrabiblical evidence concerning Nabonidus's sojourn in Teima for 10 years, which is the historical kernel behind this chapter, supports the interpretation here as "years." For a discussion of the literary and historical background of this chapter, see, e.g., Collins, Daniel, 217-19; M. Henze, The Madness of King Nebuchadnezzar: The Ancient Near Eastern Origins and Early History of Interpretation of Daniel 4, JSJs 61 (Leiden: Brill, 1999), 51-73; Carol A. Newsom, "Why Nabonidus? Excavating Traditions from Qumran, the Hebrew Bible, and Neo-Babylonian Sources," in The Dead Sea Scrolls: Transmission of Traditions and Production of Texts, ed. Sarianna Metso, Hindy Najman, and Eileen Schuller, STDJ 92 (Leiden: Brill, 2010), 57-79; and R. G. Kratz, "Nabonid in Qumran," in Wissenskultur in Orient und Okzident, ed. Eva Cancik-Kirschbaum, Margarete van Ess, and Joachim Marzahn, Topoi: BsAW 1 (Berlin: Walter de Gruyter, 2011), 253-70.

19 John E. Goldingay, Daniel, швс 3 (Nashville: Thomas Nelson, 1989), 144, n. 4e-e; 146, n. 25 d.

20 So Bevan, Daniel, 126; Montgomery, Daniel, 312; Charles, Daniel, 194; Hartman and Di Lella, Daniel, 204, 261 (translate "two years" without comment); Newsom, Daniel, 366. A. Lacocque, (The Book of Daniel, trans. D. Pellauer [Atlanta: John Knox, 1979], 154) translates "two years" and suggests that this is one of the earliest examples of the rabbinic principle of interpreting unspecified plural forms as referring to two.

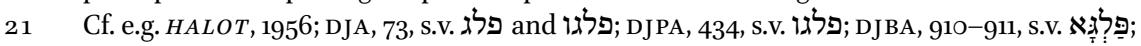
M. Sokoloff, A Syriac Lexicon: A Translation from the Latin, Correction, Expansion, and Update of C. Brockelmann's Lexicon Syriacum (Winona Lake: Eisenbrauns; Piscataway: Gorgias, 2009), 1194, s.v. هلح 
reading Daniel 7 on its own terms does not lead to the 3.5 years interpretation, and instead needs to be read in light of its apocalyptic and eschatological context. ${ }^{22}$

An internal analysis of the apocalypse in Daniel 7 leads to a different understanding of the expression עדן (ו)עדנין. The noun עדן appears twice in the apocalypse, in 7:25 (the verse under discussion) and in 7:12:

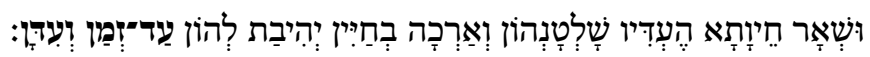

The dominion of the other beasts was taken away, but an extension of life was given to them until a time and season.

Within the context of the apocalypse, the other beasts, which reflect the heavenly representatives (or function as symbols) of the first three empires in the four kingdom scheme, were removed from their positions of authority, but re-

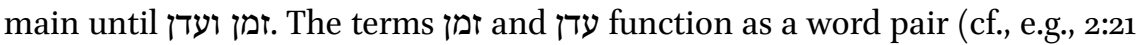
["he changes times and seasons"]), והוא מהשנא עדניא וזמניא is not related to a yearlong period or any multiple thereof. Rather, they refer to a point in time, although that time is left unspecified. The use of the Aramaic preposition ער in this verse indicates that the extension will continue until a specific endpoint, and the use of the word pair serves as emphasis for this moment, which I suggest based on the context should be understood as the eschaton. Each of the three beasts was removed from dominion, and their empires fell from glory. However, they do not disappear completely until זמן ועדן, at which time all the empires will disappear and dominion will pass to the "one like a man" (vv. 13-14).

22 This has been recognized previously by a few scholars. Montgomery, Daniel, 312-15, identifies two interpretive options for the expression in 7:25. He proposed a "definite," "exact" approach (3.5 years) or an "indefinite era" expressed "in apocalyptic fashion" (cf. the apocalyptic interpretation to be suggested below, although it is based upon a different reading than he suggests). Goldingay, Daniel, 181, asserts that this expression "is not a cryptic way of saying $3^{1 / 2}$ years" and distinguishes between 7:25 and the chronological data in chapters 8-12. Instead, he posits that the sequence of elements in this expression refers to an unspecified "time that threatens to extend itself longer," which is "brought to a sudden termination." Seow, Daniel, 112, refers to the general 3.5 year interpretation of the expression in 7:25 as "somewhat of a stretch," which in any event does not precisely reflect the events during Antiochus's reign. His interpretation of 7:25 focuses on the finite aspect of עדן for the description of human rule, as opposed to eternal divine rule in v. 27. Cf. also Eccl 3:1; Tg.Jon. Judg 17:10; Tg. Esth. 1:13. 
This seems to be the sense of v. 22 that uses the term זמן by itself:

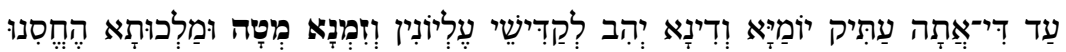

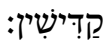

(I looked on as that horn made war with the holy ones and overcame them,) until the Ancient of Days came and judgment was rendered in favor of the holy ones of the Most High, for the time had come, and the holy ones took possession of the kingdom.

DAN 7:22 NJPS

This verse describes "the time," following the horn's struggle with the holy ones, when the Ancient of Days will rule against the horn, and the holy ones will receive dominion over the kingdom. The use of זמן here in v. 22 matches that of זמן ועדן in v. 12, and both refer to the moment at which the kingdoms of the world will disappear, and dominion will be given to קדישי עליונין. Neither case refers to a measurement of time, such as a year, but rather to a turning point when the world will undergo dramatic change.

The textual witnesses to $7: 25 \mathrm{~b} \beta$ attest to two slightly different readings, although I suggest this discrepancy is crucial for its interpretation.

\section{Reading 1:}

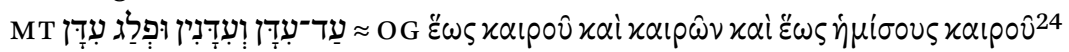
$(\approx$ Theod, Vulgate)

Reading 2:

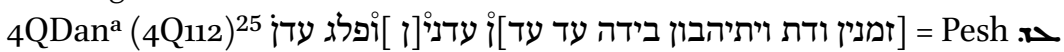

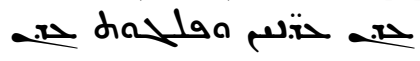

The two versions are almost identical, with one minor difference: the presence of the copulative waw in between עדנין in Reading 1. I suggest that further evidence for Reading 2 can be adduced from the corresponding passage

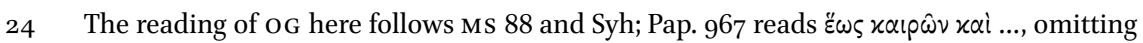
xaıpov xai due to parablepsis. The repetition of the preposition है $\omega \varsigma$ prior to "half a time" is probably for stylistic reasons alone.

25 The text here is quoted according to E. C. Ulrich, "112. 4QDana," in Qumran Cave 4.XI: Psalms to Chronicles, ed. E. C. Ulrich and Peter W. Flint, DJD 16 (Oxford: Clarendon, 20oo), 239-54, at 252. 


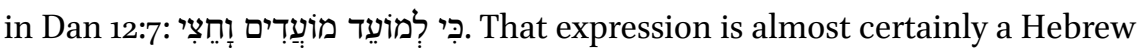
translation of 7:25, מועד and and it lacks a waw between מועדים

The small divergence between the two readings could admittedly be a minor stylistic difference. If, however, we assess Reading 2 on its own merits, then we can offer an alternative, independent explanation of its meaning. Instead of taking the first two elements in Reading 2, עדן עדנין, as individual components in a list, they can be understood as two nouns in a construct relationship. This is, in fact, how both Theodotion and the Vulgate translate מועד מועדים in

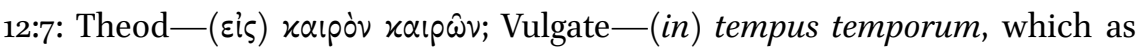
suggested above goes back to Reading 2 of 7:25. This reading, which can be translated as "time of times," can be best understood as a superlative, "the ultimate/final time," as in other instances of the use of a substantive followed by the same substantive in plural. ${ }^{28}$ In light of the analysis above of 7:12 and 22, this "time of times" or "final time" would similarly refer to the eschaton. The use of the superlative is appropriate to the style and context of Daniel 7, which

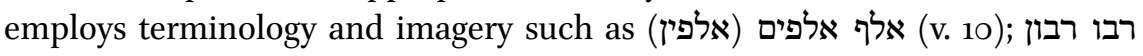

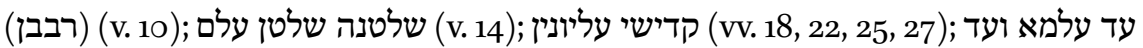
עלם עלמיא (v. עד סופא (v. 26); מלכותה מלכות עליו (v. 27).

Thus the first part of the expression in 7:25b $\beta$, according to Reading 2, can be translated: "and they will be delivered into his power until the final time." This matches perfectly the apocalyptic worldview of this chapter, which stands at the end of the Aramaic section of the book. I suggest that Reading 1 was created by a copyist who misunderstood עדן עדניץ in Reading 2 as two separate items in a list and, therefore, added a waw, which is linguistically justifiable in such a case. However, it altered the text from its original meaning.

What remains to be explained is ופלג עדץ. Most translators and commentators suggest that this term should be translated as "half a time/year," in line with the general 3.5 years interpretation. The translation of פלג as "half" reflects its most common meaning, and this translation is even more tempting in light of the use of the Hebrew term ו1 in the parallel Hebrew expression in 12:7.

26 Note the theory of Ginsberg (Studies, 41-61), that the Hebrew sections of Daniel were translated from Aramaic (esp. p. 61 regarding the verb חצ in 11:4 with the meaning "to divide [into more than two parts]" which he suggests is a translation of the Aramaic פל"ג.) Although the overall theory of a Hebrew translation of an Aramaic text is not convincing, it makes sense that a bilingual author would employ calques that do not completely semantically overlap, leading to the impressive list of examples adduced by Ginsberg.

27 The Old Greek of 12:7 translates हiऽ xalpòv xai xalpoù but this is almost certainly a harmonistic correction towards 7:25 (according to Reading 1).

28 GKC §133і; Joüon-Muraoka §141l; cf. e.g., Gen 9:25; Isa 34:10; Ezek 16:7; 26:7; Eccl 1:2. Note that according to this interpretation, there is no need to posit that the form עדנין is a dual form or has dual meaning. 
However, I suggest that this Aramaic expression can be best understood in the light of what I believe is its equivalent Hebrew expression. The Aramaic verb פלג means "separate, divide," and is cognate with the Hebrew root with the verb carrying the meaning "divide," and the substantive having the meaning "part, portion." I propose that the noun פלג in Dan 7:25 corresponds

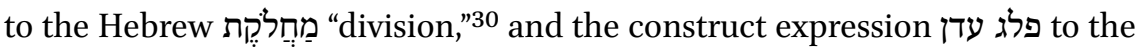

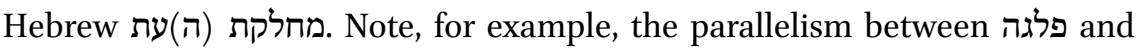
מחלקה in Ezra 6:18:

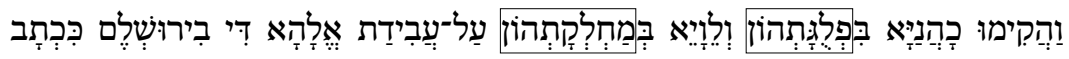

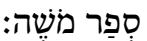

They appointed the priests in their courses and the Levites in their divisions for the service of God in Jerusalem, according to the prescription in the Book of Moses.

Ezra 6:18 NJPS

Furthermore, the biblical Hebrew term מחלקת (in its different shades of meaning) is translated consistently in the Peshitta and in the Targumim, by nominal

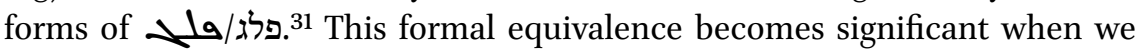
notice that the construct expression מחלקת העת "division/part of time" is attested in both singular (4Q228, see below), and in plural forms in Qumran manuscripts (the plural forms are attested primarily in Jubilees manuscripts from Qumran). ${ }^{32}$ These attestations are all found in apocalyptic contexts, according to which the events of history unfold according to clearly defined chronological periods and patterns, and occur according to set "divisions of times." 33

29 This claim can be demonstrated by the use of פל / a a a a standard translational equivalent of חל חל in the Peshitta and the Aramaic Targumim.

30 BDB, 324-25; HALOT, 569-70; DCH 5:219-20; M. Z. Kaddari, A Dictionary of Biblical Hebrew [Hebrew] (Ramat-Gan: Bar-Ilan University Press, 2006), 6oo. In biblical Hebrew, the term is used in two primary contexts: portions of inheritance (which are divided), and in LBH priestly and levitical "divisions," by which they were organized. Note $\mathrm{DCH}, 22 \mathrm{O}$, meaning (4), "division of time, season," in which all of the Qumran examples adduced here are recorded.

31 Peshitta: Josh 11:23; 18:10; Ezek 48:29; 1Chr 24:1; 26:1, 12, 19; 27:1-15; 28:1, 21; 2 Chr 31: 15-17; Targumim: Josh 11:23; 12:7; 18:10; Ezek 48:29; 1 Chr 23:6; 24:1; 26:1, 12, 19; 27:1-15; 28:1, 13, 21; 2 Chr 8:14; 23:8; 31:2,15-17; 35:4, 10.

32 Cf. also CD 16:3, ספר מחלקות העתים; and 4Q384 9:2, [ים [ים מלקות העת מים].

33 D. Dimant, "What is 'The Book of the Divisions of Times?" in Shai le-Sara Japhet: Studies in the Bible, Its Exegesis and Its Language, ed. M. Bar-Asher et al. (Jerusalem: Bialik Institute, 2007), 273-85 (Hebrew), provides an extensive discussion for the background of this expression. While I agree with most of her analysis, the discussion here suggests that is not specifically a sectarian term, since it appears in Aramaic in Dan 7:25. 
The expression is especially prominent in the opening chapter of Jubilees (Prologue, 1:4, 26, 29) and at its conclusion (50:13), which emphasize that the "divisions of times" span from the time of creation all the way until the eschaton, at which time there will be a new creation. It also appears a number of times in a fragmentary scroll (4Q228), published in DJD 13. This scroll, dated paleographically to $5 \mathrm{O}-25 \mathrm{BCE}$, was entitled "Text with a Citation of Jubilees," but seems instead to be the remains of a previously unknown eschatological composition. ${ }^{34}$ Fragment 1, col. $i$, is the best preserved of the scroll and is the passage relevant to our discussion: ${ }^{35}$

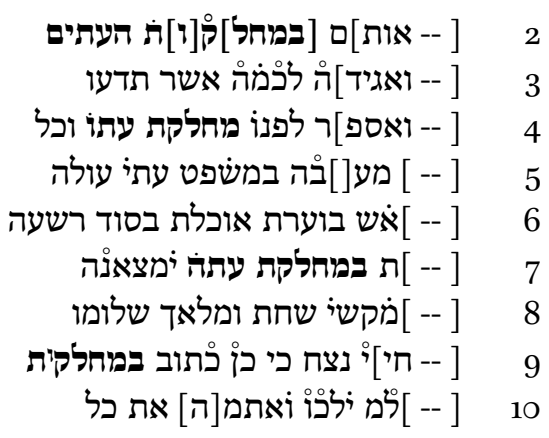

$2 \quad$ [the]m [in the divi]s[ion]s of the times

3 [and I tol]d you so that you may know

4 [and I recoun] ted before him the division of its/his time and all

5 [] $m$ [ [] $b h$ in the judgment of times of wickedness

6 [] a fire burning, devouring in a council ${ }^{36}$ of evil

7 [] $t$ in the division of its/her time he will find it/her

8 [] snares of destruction, and the angel of his peace

9 [lif]e of eternity. For thus is it written in the division ${ }^{\mathrm{s}}$

$10 \quad[] / m$ they will walk. And yo[u] all the

Therefore, it needs to be considered as part of a broader eschatological worldview, and not limited to sectarian ideology.

34 J. C. VanderKam and J. T. Milik, "228. 4QText with a Citation of Jubilees," in Qumran Cave 4.VIIII: Parabiblical Texts, Part 1, eds. H. W. Attridge et al., DJD 13 (Oxford: Clarendon Press, 1994), 177-85. See already the discussion in Dimant, "The Book of the Divisions of Times," in which she convincingly argues that line 9 does not refer to the book of Jubilees, which renders the name assigned to the scroll problematic.

35 The text and translation follow VanderKam and Milik, "4Q228," 178-81, with minor modifications.

36 VanderKam and Milik, "4Q228," 18o, translate "foundation of evil," but the relevant sources they adduce from sectarian literature (see " $4 \mathrm{Q}_{228}$," 182) support the translation "council" (used in parallel to עדה/עצה). 
While the precise details of this passage are not fully clear, it appears to describe the events of various periods of history, including those of the addressee (line 4). These periods include "times of wickedness" (line 5) to be accompanied by judgment, with burning and devouring of a "council of evil" (line 6). There appears to be a transition in line 8 from a time of judgment and destruction to a more positive reality, accompanied by "the angel of his peace" and "eternal (life?)" (line 9). These are recorded in "the divisions [of times]" (lines 9-10), either a reference to an actual literary composition or, more likely in my opinion, a heavenly register of the periods of history. Here too, the eschatological context of the expression מחלקת העת is palpable.

פלג עדן In light of this analysis, I suggest that it is preferable to translate in Dan 7:25 not as "half a year," but rather, as "and the division of (the) time." How does this phrase relate to the previous clause "and they will be delivered into his power until the final time"? The simplest approach is to posit that "the division of time" is synonymous to "the time of times," and they both reflect objects of the preposition עד referring to the same final period of history. This repetition could then perhaps be seen as added for emphasis. ${ }^{37}$ This proposed interpretation for Dan 7:25, without recourse to the later chapters of Daniel, offers a completely different perspective of the end of this apocalypse than the general interpretation of 3.5 years until the end of Antiochus's decrees, and broadens its original chronological horizon to an unknown end-point, consistent with other apocalyptic visions. This supports the conclusion that the apocalypse in its current form was composed at some point in time after the beginning of Antiochus's decrees in $167 \mathrm{BCE},{ }^{38}$ but prior to the rededication of the Temple in 164 , at which time such a dramatic perspective was a matter of speculation and wild hope. ${ }^{39}$

37 In Segal, "Calculating the End," $283-86$, due to the redundancy created by assuming that the two expressions are in fact synonymous, I offered a second, more complex, interpretation of the meaning and syntactic function of ופלג עדן. This included an alternate verse division, moving it to the beginning of v. 26, leading to a picture according to which the final divine judgment will take place in the last (sub-)division of time prior to the eschaton, a theme that finds parallels in additional apocalyptic compositions (see especially the Apocalypse of Weeks in 1 Enoch 91).

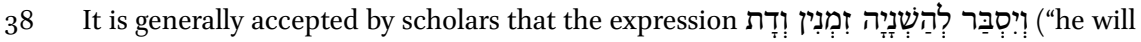
think of changing times and laws") in Dan 7:25 is a reference to these decrees. It is perhaps possible to date this apocalypse even more precisely, since there is no mention here of the actual profanation of the Temple. This suggests that it was composed in late $167 \mathrm{BCE}$, after the decrees but before the profanation (cf. e.g., Collins, Daniel, 323-24).

39 Thus despite the suggestion here of an eschatological perspective at the heart of $7: 25$, this does not alter the generally accepted date of composition for this apocalypse in its current form. 
A similar situation obtains in Daniel 11, when one realizes (as scholars previously have) that the chronological data following this apocalypse, in 12:7, 11, 12, is secondary to the chapter. In fact, the original end of the apocalypse, and perhaps of the book of Daniel as a whole, was probably in 12:4 ("But you, Daniel, keep the words secret, and seal the book until the time of the end. Many will range far and wide and knowledge will increase"), followed by a secondary expansion or appendix in 12:5-13. ${ }^{40}$ This leaves us with another apocalypse, Daniel 11, which in its original form did not include a specific date by which Antiochus's decrees would end. Rather, it refers more generally to times using the terms (11:27, 35).

Scholars have long noted that this apocalypse can be divided into 11:1-39, which refers to events that came to fruition, and 11:40ff., which does not match the historical reality. ${ }^{41}$ Therefore, the general scholarly consensus for dating the apocalypse in Daniel 11 is prior to Antiochus's death in Persia in 164 ВCE (since he perished under different circumstances than those described in 11:40-45), and consequently prior to the end of the decrees in December 164 BCE. We can, therefore, identify a common characteristic of Daniel 7 and 10:1-12:4, both of which were composed prior to the end of Antiochus's decrees, and neither of which hazarded a guess to predict their end. Instead both spoke generally of a time, ממן in Daniel 7, and מועד and Daniel 11-12.

Before analyzing the other passages in the Daniel apocalypses that address the end of the persecution, it is important to briefly mention the extraDanielic sources that describe for how long it continued, and in particular the

40 Many scholars have noted that 12:4 functions as a conclusion to the vision in chapters 10-11. Daniel 12:5-13 constitutes a new literary unit, which functions as an appendix; see G. A. Barton, "The Composition of the Book of Daniel," JBL 17 (1898): 62-86, at 77; Montgomery, Daniel, 474; Ginsberg, Studies, 30-31; Hartman and Di Lella, Daniel, 261, 310-15; Lacocque, Daniel, 181-83; Collins, Daniel, 371; Seow, Daniel, 191-92; Newsom, Daniel, $365^{-68}$. While there is general agreement about the division between the two sections, scholars disagree about the origins of the appendix. Montgomery, Lacocque, and Collins view 12:5-13 as a passage composed by the same author as 10:1-12:4 (except perhaps for 12:11-12 which are identified as scribal, chronological "updates"). In contrast, Barton, Ginsberg, Hartman and Di Lella, and Seow view the appendix as a secondary addition to the book (see especially Ginsberg, Studies, 30-38 [followed by Hartman and Di Lella], who reconstructs a complex process of secondary accretions by a number of scribal hands). As I argued in "The Text of Daniel in the Dead Sea Scrolls", Meghillot 11-12 (2015): 171-98, at 188-9o (Hebrew), I am of the opinion that the appendix is a secondary addition to the previous vision(s), which subtly reformulates certain elements in Daniel 11 in order to include the "many" (רבים) in what was originally described as limited to the משכילים (I suggest this term should be translated as "teachers"). In particular, compare the reformulation of 11:33 and 35 in 12:10. 
desecration of the Temple and its cult. The most explicit chronological information about the length of this desecration, including the dates of both the desecration and rededication, is found in both First and Second Maccabees. ${ }^{42}$

1 Macc 1:54, 59: (54) And on the 15th day of Chaseleu in the 145th year, he constructed an abomination of desolation on the altar, and in the cities around Iouda they built altars ... (59) On the 25th of the month they were sacrificing on the altar that was on top of the sacrificial altar.

1 Macc 4:52-54: (52) And they arose on the morning of the 25th of the ninth month, this being the month Chaseleu, of the 148th year, (53) and they offered sacrifice according to the law on the new altar of whole burnt offerings that they made. (54) During the same time and on the same day on which the nations defiled it, on that day it was rededicated with songs and lyres and cinyras and cymbals.

2 Macc 10:5: It happened that on the same day on which the shrine had been profaned by allophyles the purification of the shrine took place, that is, on the 25th day of the same month, which was Chaseleu. ${ }^{43}$

According to 1 Maccabees, the profanation of the altar lasted for precisely three years from the $25^{\text {th }}$ of Kislev in the 145th year of the Seleucid count $(=167$ BCE) until the same date three years later in 164 в Се. ${ }^{44}$ Whether or not this information reflects historical reality, ${ }^{45}$ it is highly significant that the same (or a similar) tradition, and emphasis of that tradition, appears in both of these books. ${ }^{46}$

42 For a clear presentation of the dates surrounding the profanation and rededication of the Temple, cf. J. A. Goldstein, II Maccabees: A New Translation with Introduction and Commentary, AB 41A (Garden City, NY: Doubleday, 1983), 115-18.

43 The translations here follow the New English Translation of the Septuagint (NETS).

44 As can be seen from the dates in 1 Maccabees, the period of three years measured the time from the offering of foreign sacrifices on the Temple altar, and not the erection of the abomination, which took place ten days earlier. In any event, the period of three years and ten days is not identical to any of the sources in Daniel.

45 The emphasis on the beginning and end occurring on the same date might reflect a literary-theological motif that emphasizes divine justice and involvement in history; see I. Gafni, "Concepts of Periodization and Causality in Talmudic Literature," JH 10 (1996): 21-38, at 28-29.

46 According to 2 Macc 10:3, 5, the cessation of the daily sacrifice lasted precisely two years, and not three, as in 1 Maccabees. For the background of this chronological anomaly, see Goldstein, II Maccabees, 55-63; D. R. Schwartz, 2 Maccabees, CEJL (Berlin: Walter de 
At a minimum, we can conclude that following the rededication of the Temple, there was a widespread understanding that the profanation lasted for precisely three years. At a maximum, this indeed reflected the reality behind the events.

Three passages in Daniel provide precise periods of time for the length of the persecution, although they are not identical to the three-year period of 1 Maccabees. I suggest that this discrepancy is the result of an attempt to conform the reference to the eschaton in Dan 7:25 to the historical reality, following the cessation of the religious persecution and desolation of the Temple.

\subsection{Daniel 9:27}

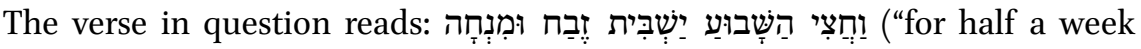
he will put a stop to the sacrifice and the meal offering"). This is an allusion to Antiochus's profanation of the altar in the final week of the seventyweek scheme in the vision. Scholars correctly delimit this "week" between 171-164 в СE, beginning with the murder of the "anointed one," the high priest Onias III (cf. Dan 11:22 and 2 Macc 4:30-38), and ending with the cessation of Antiochus's decrees. ${ }^{47}$ Since this chapter refers to weeks of seven years, then a period of half a week can be easily calculated as 3.5 years. If this is the case, then this would perhaps be early evidence for reading 7:25 as "a year, (two) years, and half a year." ${ }^{38}$ This apocalypse, which assigns a finite measure to the period until the end of Antiochus's profanation of the Temple, is most likely an ex eventu prophecy, composed following the end of the profanation. This explains the general accuracy regarding the length of the desecration. ${ }^{49}$

Gruyter, 2008), 372-73, who both suggest that it is an error that can be understood as the result of the editorial process by which 2 Maccabees was composed. In any event, the emphasis "on the same day" in 2 Maccabees seems to reflect the same tradition as in 1 Maccabees.

47 Hartman and Di Lella, Daniel, 252; Lacocque, Daniel, 196-97; Collins, Daniel, 356-58; Newsom, Daniel, 306-7.

48 Numerous scholars assume this equivalence, and use it to interpret 7:25, e.g., Hartman and Di Lella, Daniel, 215; Lacocque, Daniel, 154; Collins, Daniel, 357; Newsom, Daniel, 267, 366 (referring to 12:7). Montgomery, Daniel, 386, first notes that a "half-week" = 3.5 years, but then notes that this period is so close to the three years of 1 Maccabees that it allows for the possibility of viewing this statement as either "prophetic or post eventum."

49 Contra those who suggest that this was a "genuine prediction" written before December 164 BCE, since it "slightly overshot its mark" and, therefore, would not have been written ex eventu (see e.g., Hartman and Di Lella, Daniel, 253). 
6.2 Daniel 12:11-12

A more precise analysis is possible in reference to this passage:

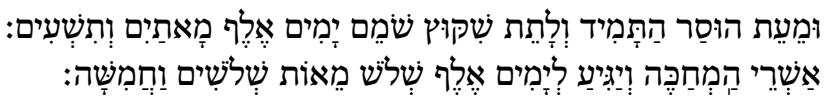

From the time the regular offering is abolished, and an appalling abomination is set up - it will be a thousand two hundred and ninety days. Happy the one who waits and reaches one thousand three hundred and thirty-five days.

DAN 12:11-12 NJPS

Verse 11 counts a specific number of days from the time of the cessation of the daily offering and the erection of the "appalling abomination" and is presented as a further clarification of the response (12:7) to the question posed just a few verses earlier (12:6). Since we have the beginning and endpoint of this period, and the total number of days included, we can, therefore, calculate the number of years intended. Calculation according to either the lunisolar or solar calendars, both of which were employed by Jews in the second century BCE, lead to a "prediction" of almost precisely 3.5 years. ${ }^{50}$

Here too, as in 9:27, the chronological datum in this verse is the result of inner-Danielic scribal exegesis, whereby 7:25 was interpreted in order to clarify the length of time during which the temple was profaned. This precise period of time is not based upon historical analysis or traditions, but is rather the result of a scholastic, hermeneutic investigation into the earlier Danielic passage. This insight offers an explanation as to the deviation between the length of the persecutions in 1 Maccabees and Daniel, and should obviate the (many) attempts to identify specific historical events that took place at the beginning and end of a 3.5-year (or 1,290 or 1,335 days) period, since these numbers are in fact unrelated to the historical reality. At the same time, it seems safe to postulate that these verses were composed after the events in question took place, when there was no risk of having the prediction proven wrong. ${ }^{51}$

50 See Segal, "Calculating the End," 294-96.

51 Contra the many scholars who assume that 12:12 "updates" the prediction in 12:11 that did not come to fruition. If 12:12 was intended as an extension to the original predictive prophecy, then adding only forty-five days would be a very risky proposition. I plan to address the significance of this forty-five day difference in a subsequent publication. 


\subsection{Daniel 8:13-14}

In the final verses under investigation here, there is an explicit heavenly question and answer about the length of time for the cessation of the daily offering:

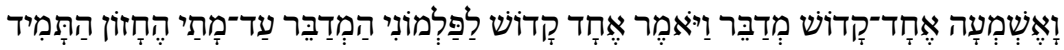

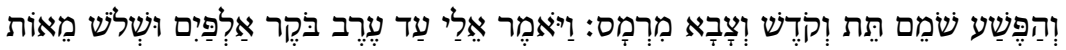

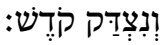

Then I heard a holy being speaking, and another holy being said to whoever it was who was speaking, "How long will [what was seen in] the vision last - the regular offering be forsaken because of transgression; the sanctuary be surrendered and the [heavenly] host be trampled?" He answered me, "For twenty-three hundred evenings and mornings; then the sanctuary shall be cleansed".

DAN 8:13-14 NJPS

As has been noted by many commentators, the verses refer to the תמיד, the daily offering, offered twice daily, in the morning and in the evening (Exod 29:3839; Num 28:3-4). Therefore, the number explicitly noted here, 2,300, refers to the total number of offerings, which should be double the number of days. ${ }^{52}$ According to this calculation, the number of days during which the daily offering was forsaken was $1,15 \mathrm{O}(2,300 / 2)$. This period is less than the 3.5 years of 12:11, but more than the 3 years of 1 Maccabees. Due to the discrepancy with 1 Maccabees, Collins concluded that "the prediction, then, cannot be after the fact and must have been composed before the actual rededication of the temple. ${ }^{53}$ Due to the seeming discrepancy with the 3.5-years tradition (which Collins identifies in 7:25 as well), he suggests that Daniel 8 was composed a short while after Daniel 7 , and thus it starts its count from a later point.

52 Montgomery, Daniel, 242-43; Hartman and Di Lella, Daniel, 227; Lacocque, Daniel, 164; Collins, Daniel, 336; Newsom, Daniel, 267. In contrast, Goldingay, Daniel, 213; Seow, Daniel, 125, understand "evening and morning" as a reference to a complete day (in light of Genesis 1) and, therefore, view the period as 2,30o days. This reading is already attested in antiquity, and both OG and Theod have an additional word $\eta \mu \varepsilon$ pal ("days") prior to the number 2,300. Seow, therefore, begins the count in $171 \mathrm{BCE}$ from the time of the murder of Onias III (a possibility also suggested by Goldingay). Goldingay also posits that the period of 2,300 days is a "fixed 'significant' period" that reflected a complete unit of time.

53 Collins, Daniel, 336; similarly Bevan, Daniel, 127-28; and Newsom, Daniel, 267. Lacocque, Daniel, 250, describes 8:14 as "an exact calculation ... of the period during which the cultus was interrupted in Jerusalem (Autumn 167 to 14 December, 164)," although he does not demonstrate how this is possible mathematically. 
In contrast, in light of the analysis above, I suggest that 8:13-14 should be read as an interpretation of 7:25, since the latter in its original context did not refer to a specific time. As has been noted by many scholars, and can be demonstrated by the use of common language and motifs, the author of Daniel 8 is aware of and even reuses material from Daniel 7 throughout the chapter (e.g., the motif of the horn battling against the heavenly forces). ${ }^{54}$ Thus it seems likely that he knew of the expression עדן (ו)עדנין ופלג עדן from 7:25.

With this in mind, how does Dan 8:13-14 function as an interpretation of 7:25? I previously suggested that 8:13-14 is an attempt to bridge the chronological data found in Daniel (3.5 years) with that reflected in 1 Maccabees (three years), while interpreting the expression פלג עדן of 7:25 as "part of a year."55 In a future study, I will suggest a new approach $-2,300$ indeed refers to the number of tamid offerings. However, a specific reading of the biblical laws in Leviticus 23 and Numbers 28-29 regarding the daily service, attested perhaps in the laws of the Damascus Document, allows for the possibility that they were not offered on sabbaths and festivals. When these days are discounted, then 2,300 tamid offerings can be mapped onto a period of 3.5 years, found elsewhere in the Danielic apocalypses, in 9:27 and 12:11-12. ${ }^{56}$

The use of specific, definite chronological details in these passages demonstrates that they were composed following the end of the Antiochian decrees. This chronological insight also corresponds to the culmination of each of the apocalypses. In the case of the four kingdoms is chapters 2 and 7 , the final stage, at the eschaton, is followed by a radical geopolitical transformation of the world order. Similarly, 11:40-12:4 describes Antiochus's predicted demise "between the sea the beautiful holy mountain" and ultimate judgment for the universe, as is common in eschatological compositions. ${ }^{57}$ In contrast, the apocalypses in chapters 8 and 9, do not describe a major transformation of the world order or general judgment, but rather, both describe the eventual demise of the persecuting king:

54 So e.g., Hartman and Di Lella, Daniel, 23o; Collins, Daniel, 342; and Kratz, "Visions of Daniel," 99-105.

55 See the calculations for both calendars in Segal, "Calculating the End," 291-94.

$5^{6}$ This was presented as a lecture at the гоsот Aberdeen 2019 conference, and will be published in a future study.

57 See, e.g., the expression "the day/time of (great) judgment" in an eschatological context, in 1 En. 10:6, 12 (4QEn ${ }^{\mathrm{b}} 1$ iv, 11, in J. T. Milik, The Books of Enoch: Aramaic Fragments of Qumrân Cave 4 [Oxford: Clarendon, 1976], 175), 14 (4QEnc 1 v, 2 [ibid., 189]); 16:1; 22:4 (4QEn ${ }^{\mathrm{e}} 1$ xxii, 2-3 [ibid., 229]), 13 (4QEn ${ }^{\mathrm{d}} 1$ xi, 1 [ibid., 218]); Jub. 4:19; 5:10; 9:15; 10:17, 22; 22:21; 23:11; 24:30, 33 . 
By his cunning, he will use deceit successfully. He will make great plans, will destroy many, taking them unawares, and will rise up against the chief of chiefs, but will be broken, not by [human?] hands.

DAN 8:25 NJPS

During one week he will make a firm covenant with many. For half a week he will put a stop to the sacrifice and the meal offering. At their corner will be an appalling abomination until the decreed destruction will be poured down upon the appalling thing.

DAN 9:27 NJPS, revised

Both of these apocalypses describe supernatural interventions in order to overthrow the king and put an end to the desecration of the Temple. But this does not necessitate a dramatic, eschatological change in the world order.

The different nature of these apocalypses, chapters 2,7 , and 10-12 with an eschatological climax, and chapters 8 and 9 with a supernatural, yet historically bounded, end to the Antiochian persecutions, are a direct result of the dates of composition as outlined above. The former were composed during the height of the persecution; therefore, the authors could only imagine a distant salvation. The latter were composed following their completion. Although these later apocalyptic authors credited God for their salvation, they could conceive of this delivery in historical terms. The Danielic authors' chronological framework is, therefore, fundamentally bound up with their theological worldview, and in particular, their historical and eschatological perspective.

\section{Bibliography}

Barton, G. A. "The Composition of the Book of Daniel." JBL 17 (1898): 62-86.

Bevan, Anthony A. A Short Commentary on the Book of Daniel: For the Use of Students. Cambridge: University Press, 1892.

Brown, Francis, S. R. Driver, and Charles A. Briggs. A Hebrew and English Lexicon of the Old Testament. Oxford: Clarendon, 1907.

Charles, Robert H. A Critical and Exegetical Commentary on the Book of Daniel. Oxford: Clarendon, 1929 .

Clines, David J. A., ed. Dictionary of Classical Hebrew. 9 vols. Sheffield: Sheffield Phoenix, 1993-2016.

Collins, John J. "The Meaning of 'the End' in the Book of Daniel." Pages 91-98 in $O f$ Scribes and Scrolls: Studies on the Hebrew Bible, Intertestamental Judaism, and 
Christian Origins: Presented to John Strugnell on the Occasion of His Sixtieth Birthday. Edited by H. W. Attridge, John J. Collins, and Thomas H. Tobin, S.J. CTSRR 5. Lanham: University Press of America, 199o.

Collins, John J. A Commentary on the Book of Daniel. Hermeneia. Minneapolis: Fortress, 1993.

Dimant, Devorah, ed. “B. Apocryphon of Jeremiah." Pages 91-26o in Qumran Cave 4.XXI: Parabiblical Texts, Part 4: Pseudo-Prophetic Texts. DJD 30. Oxford: Clarendon, 2001.

Dimant, Devorah. "What is 'The Book of the Divisions of Times?" Pages 273-85 in Shai le-Sara Japhet: Studies in the Bible, Its Exegesis and Its Language. Edited by M. Bar-Asher et al. Jerusalem: Bialik Institute, 2007 (Hebrew).

Flusser, David. "The Four Empires in the Fourth Sybil and in the Book of Daniel." Ios 2 (1972): 148-75.

Gafni, I. “Concepts of Periodization and Causality in Talmudic Literature." JH 10 (1996): $21-38$.

Gesenius, Wilhelm. Gesenius' Hebrew Grammar. Edited by Emil Kautzsch. Translated by A. E. Cowley. London: Oxford University Press, 1910.

Ginsberg, H. L. Studies in Daniel. TS 14. New York: Jewish Theological Seminary of America, 1948.

Goldingay, John E. Daniel. wвс 3о. Nashville: Thomas Nelson, 1989.

Goldstein, J. A. II Maccabees: A New Translation with Introduction and Commentary. АВ 41A. Garden City, NY: Doubleday, 1983.

Hartman, Louis F. and Alexander A. Di Lella. The Book of Daniel:A New Translation with Introduction and Commentary. AB 23. Garden City, NY: Doubleday, 1978.

Henze, M. The Madness of King Nebuchadnezzar: The Ancient Near Eastern Origins and Early History of Interpretation of Daniel 4. J Jjs 61. Leiden: Brill, 1999.

Joüon, Paul and Tamitsu Muraoka. A Grammar of Biblical Hebrew. Rome: Editrice Pontificio Istituto Biblico, 2008.

Kaddari, M. Z. A Dictionary of Biblical Hebrew. Ramat-Gan: Bar-Ilan University Press, 2006 (Hebrew).

Koehler, Ludwig, Walter Baumgartner, and Johann J. Stamm. The Hebrew and Aramaic Lexicon of the Old Testament. Translated and edited under the supervision of Mervyn E. J. Richardson. 2 vols. Leiden: Brill, 2001.

Kratz, R. G. "Nabonid in Qumran." Pages 253-70 in Babylon: Wissenskultur in Orient und Okzident. Edited by Eva Cancik-Kirschbaum, Margarete van Ess, and Joachim Marzahn. Topoi: BSAW 1. Berlin: Walter de Gruyter, 2011.

Kratz, R. G. "The Visions of Daniel." Pages 91-113 in vol. 1 of The Book of Daniel: Composition and Reception. Edited by John J. Collins and Peter W. Flint. VTSup 83. Brill: Leiden, 2001.

Lacocque, A. The Book of Daniel. Translated by D. Pellauer. Atlanta:John Knox, 1979. 
Mendels, Doron. “The Five Empires: A Note on a Propagandistic “Topos.” AJP 102 (1981): 330-37.

Milik, J. T., with the collaboration of Matthew Black. The Books of Enoch: Aramaic Fragments of Qumrân Cave 4. Oxford: Clarendon, 1976.

Montgomery, James A. A Critical and Exegetical Commentary on the Book of Daniel. ICC. Edinburgh: T\&T Clark, 1927.

Newsom, Carol A., with Brennan Breed. Daniel: A Commentary. отL. Louisville: Westminster John Knox, 2014.

Newsom, Carol. A. "Why Nabonidus?: Excavating Traditions from Qumran, the Hebrew Bible, and Neo-Babylonian Sources." Pages 57-79 in The Dead Sea Scrolls: Transmission of Traditions and Production of Texts. Edited by Sarianna Metso, Hindy Najman, and Eileen Schuller. STDJ 92 Leiden: Brill, 2010.

Portier-Young, Anathea. Apocalypse Against Empire: Theologies of Resistance in Early Judaism. Grand Rapids: Eerdmans, 2011.

Reynolds III, Bennie H. Between Symbolism and Realism: The Use of Symbolic and NonSymbolic Language in Ancient Jewish Apocalypses 333-63 B.C.E. JAJSup 8. Göttingen: Vandenhoeck \& Ruprecht, 2011.

Schwartz, D. R. 2 Maccabees. CEJL. Berlin: Walter de Gruyter, 2008.

Segal, Michael. The Book of Jubilees: Rewritten Bible, Redaction, Ideology and Theology. JsJs 117. Leiden: Brill, 2007.

Segal, Michael. "The Chronological Conception of the Persian Period in Daniel 9." JAJ 2 (2011): 283-303.

Segal, Michael. "The Text of Daniel in the Dead Sea Scrolls." Meghillot 11-12 (2015): 171-98 (Hebrew).

Segal, Michael. Dreams, Riddles, and Visions: Textual, Contextual, and Intertextual Approaches to the Book of Daniel. BZAW 455. Berlin: Walter de Gruyter, 2016.

Segal, Michael. "Calculating the End: Inner-Danielic Chronological Developments." VT 68 (2018): 272-96.

Segal, Michael. "Interpreting History in Qumran Texts." Pages 212-44 in The Religious Worldviews Reflected in the Dead Sea Scrolls: Proceedings of the Fourteenth International Symposium of the Orion Center for the Study of the Dead Sea Scrolls and Associated Literature. Edited by M. Kister, M. Segal, and R. Clements. STDJ 127. Leiden: Brill, 2018.

Seow, Choon-Leong. Daniel. wм вс. Louisville: Westminster John Knox, 2003.

Sokoloff, M. A Dictionary of Jewish Palestinian Aramaic of the Byzantine Period. RamatGan: Bar Ilan University Press, 1992.

Sokoloff, M. A Dictionary of Jewish Babylonian Aramaic of the Talmudic and Geonic Periods. Ramat-Gan: Bar Ilan University Press, 2002.

Sokoloff, M. A Dictionary of Judean Aramaic. Ramat-Gan: Bar Ilan University Press, 2003 . 
Sokoloff, M. A Syriac Lexicon: A Translation from the Latin, Correction, Expansion, and Update of C. Brockelmann's Lexicon Syriacum. Winona Lake: Eisenbrauns; Piscataway: Gorgias, 2009.

Swain, Joseph W. "The Theory of the Four Monarchies: Opposition History under the Roman Empire." CP 35 (1940): 1-21.

Ulrich, Eugene C. "112. 4QDana." Pages 239-254 in Qumran Cave 4.XI: Psalms to Chronicles. Edited by Eugene C. Ulrich and Peter W. Flint. DJD 16. Oxford: Clarendon, 2000.

VanderKam, James C. and J. T. Milik. “228. 4QText with a Citation of Jubilees." Pages 17785 in Qumran Cave 4.VIIII: Parabiblical Texts, Part 1. Edited by H. W. Attridge, T. Elgvin, J. Milik, S. Olyan, J. Strugnell, E. Tov, J. VanderKam, and S. White. DJD 13. Oxford: Clarendon Press, 1994.

VanderKam, James C. From Revelation to Canon: Studies in Hebrew Bible and Second Temple Literature. JsJs 62. Leiden: Brill, 2000. 